\title{
Quantitative analysis of DNA levels in maternal plasma in normal and Down syndrome pregnancies
}

\author{
Ilona Hromadnikova*1, Bela Houbova1, Dana Hridelova1 ${ }^{1}$, Sona Voslarova1, \\ Pavel Calda ${ }^{2}$, Katerina Nekolarova ${ }^{2}$, Josef Kofer ${ }^{3}$, David Stejskal ${ }^{4}$, \\ Jindrich Doucha ${ }^{5}$, Ondrej Cinek ${ }^{1}$ and Jan Vavrirec ${ }^{1}$
}

Address: ${ }^{1}$ 2nd Department of Paediatrics, 2nd Medical Faculty, Charles University, University Hospital Motol, Czech Republic, ${ }^{2}$ Department of Obstetrics and Gynaecology, 1st Medical Faculty, Charles University, Prague, Czech Republic, ${ }^{3}$ Department of Medical Genetics, Masaryk Hospital, Ústi nad Labem, Czech Republic, ${ }^{4}$ Department of Medical Genetics, GENNET, Prague, Czech Republic and ${ }^{5}$ Department of Obstetrics and Gynaecology, 2nd Medical Faculty, Charles University, University Hospital Motol, Prague, Czech Republic

E-mail: Ilona Hromadnikova* - ilona.hromadnikova@lfmotol.cuni.cz; Bela Houbova - ilona.hromadnikova@lfmotol.cuni.cz; Dana Hridelova - ilona.hromadnikova@lfmotol.cuni.cz; Sona Voslarova - ilona.hromadnikova@lfmotol.cuni.cz; Pavel Calda - calda@obgyn.anet.cz; Katerina Nekolarova - calda@obgyn.anet.cz; Josef Kofer - josef.kofer@mnul.cz; David Stejskal - david.stejskal@gennet.cz; Jindrich Doucha - ilona.hromadnikova@lfmotol.cuni.cz; Ondrej Cinek - ondrej.cinek@lfmotol.cuni.cz; Jan Vavrirec - jan.vavrinec@lfmotol.cuni.cz

*Corresponding author

Published: 28 May 2002

BMC Pregnancy and Childbirth 2002, 2:4
Received: 9 January 2002

Accepted: 28 May 2002

This article is available from: http://www.biomedcentral.com/I47/-2393/2/4

(C) 2002 Hromadnikova et al; licensee BioMed Central Ltd. Verbatim copying and redistribution of this article are permitted in any medium for any purpose, provided this notice is preserved along with the article's original URL.

\begin{abstract}
Background: We investigated fetal and total DNA levels in maternal plasma in patients bearing fetuses affected with Down syndrome in comparison to controls carrying fetuses with normal karyotype.

Methods: DNA levels in maternal plasma were measured using real-time quantitative PCR using SRY and $\beta$-globin genes as markers. Twenty-one pregnant women with a singleton fetus at a gestational age ranging from 15 to 19 weeks recruited before amniocentesis (carried out for reasons including material serum screening and advanced material age), and 16 pregnant women bearing fetuses affected with Down syndrome between 17 to 22 weeks of gestation were involved in the study.
\end{abstract}

Results: The specificity of the system reaches 100\% (no $Y$ signal was detected in 14 women pregnant with female fetuses) and the sensitivity $91.7 \%$ (SRY amplification in 22 of 24 examined samples). The median fetal DNA levels in women carrying Down syndrome $(n=I I)$ and the controls $(n=13)$ were 23.3 (range 0-58.5) genome-equivalents $/ \mathrm{ml}$ and 24.5 (range 0-47.5) genomeequivalents $/ \mathrm{ml}$ of maternal plasma, respectively $(P=0.62)$. The total median DNA levels in pregnancies with Down syndrome and the controls were 10165 (range 615-65000) genomeequivalents $/ \mathrm{ml}$ and 7330 (range 1300-36750) genome-equivalents $/ \mathrm{ml}$, respectively $(P=0.32)$. The fetal DNA proportion in maternal plasma was $0 \%-6 \%$ (mean $0.8 \%$ ) in women carrying Down syndrome and $0 \%-2.6 \%$ (mean $0.7 \%$ ) in the controls, respectively $(\mathrm{P}=0.86)$.

Conclusions: Our study revealed no difference in fetal DNA levels and fetal DNA: maternal DNA ratio between the patients carrying Down syndrome fetuses and the controls. 


\section{Background}

Current experimental non-invasive methods for the prenatal diagnosis of fetal genetic characteristics use free extracellular fetal DNA and fetal cells isolated from maternal peripheral blood. Free extracellular fetal DNA which can be detected by polymerase chain reaction (PCR) in the serum or plasma of pregnant women [1] has been previously successfully used for the prenatal diagnosis of fetal sex and rhesus D status [2-5]. A novel approach is to monitor elevations in the fetal DNA levels in pregnancies with preeclampsia $[7,8]$, aneuploid fetuses $[9,10]$ and preterm labor [11] using the real-time quantitative PCR technology (RQ-PCR) [6]. The study of Zhong et al. also showed that in preeclampsia, the amounts of both circulatory fetal and maternal DNA were increased [8].

In this study, we investigated the fetal and total DNA levels in maternal plasma in patients bearing fetuses affected with Down syndrome in comparison to the controls carrying fetuses with normal karyotype. The detection of $\mathrm{Y}$ DNA was used in male fetuses because a generic fetal DNA marker is not yet available.

\section{Methods}

Twenty-one pregnant women with a singleton fetus at a gestational age ranging from 15 - 19 (Ф 17.) weeks with an increased risk for an aneuploid fetus who were undergoing an invasive prenatal diagnostic procedure (amniocentesis), and 16 pregnant women bearing fetuses affected with Down syndrome between 17 - 22 ( $\Phi$ 20.) weeks of gestation were recruited for this study. Local Ethics Committee approval and informed consent was obtained for all patients in the study.

\section{DNA extraction from plasma samples}

Five ml of maternal peripheral blood from Down syndrome and euploid cases was collected into EDTA containing tubes and processed within a few hours (maximally $24 \mathrm{~h}$ ). In details, blood samples were centrifuged firstly at $1200 \mathrm{~g}$ for $10 \mathrm{~min}$., than plasma samples were recentrifuged again and the supernatants were collected and stored at $-80^{\circ} \mathrm{C}$ until futher processing. Down syndrome and euploid case samples were matched for time in storage to take under consideration an eventual loss of fetal DNA in maternal plasma as a function of time in freezer storage. The Down syndrome plasma samples were stored in a freezer for 4,6 (range 1-8) months and control samples for 5,1 (range 1-8) months before DNA extraction and RQ-PCR analyses.

DNA was extracted from $400 \mu \mathrm{l}$ plasma using QIAamp DNA Blood Mini Kit (Qiagen, Hilden, Germany) according to the manufacturer's instructions. To minimize the risk of contamination, DNA was isolated in laminar airflow and aerosol resistant tips were used. DNA was eluted in $50 \mu \mathrm{l}$ Buffer $\mathrm{AE}$ and 2,5 $\mu \mathrm{l}$ were used as a template for the RQ-PCR reaction.

\section{Real-time quantitative PCR Analysis}

The real time quantitative PCR analysis was performed using ABI PRISM 7700 Sequence Detection System (Applied Biosystem, Branchburg, New Jersey, USA). The $\beta$-globin TaqMan system consisted of two primers $\beta$-globin-354 (forward), 5'-GTG CAC CTG ACT CCT GAG GAG A-3'; $\beta$ globin-455 (reverse), 5'-CCT TGA TAC CAA CCT GCC CAG-3' and a dual-labelled fluorescent TaqMan probe $\beta$ globin-402T, 5'(FAM) AAG GTG AAC GTG GAT GAA GTT GGT GG (TAMRA)-3' [6]. The SRY TaqMan system consisted of SRY-109 (forward) primer, 5'-TGG CGA TTA AGT CAA ATT CGC-3'; SRY-245 (reverse) primer, 5'-CCC CCT AGT ACC CTG ACA ATG TAT T-3' and a probe SRY-142T, 5'(FAM) AGC AGT AGA GCA GTC AGG GAG GCA GA (TAMRA)-3' [6]. Sequence data were obtained from the GeneBank Sequence database U01317 ( $\beta$-globin gene) and L08063 (SRY gene) as was previously described by Lo et al. [6].

TaqMan amplification reactions were set up in a reaction volume of $25 \mu \mathrm{l}$ using the TaqMan Universal PCR Master Mix (Applied Biosystems, Branchburg, New Jersey, USA). DNA amplifications were carried out in 8-well reaction optical tubes/stripes (Applied Biosystem, Branchburg, New Jersey, USA). The TaqMan PCR conditions were used as described in TaqMan guidelines using 40 cycles of $95^{\circ} \mathrm{C}$ for $15 \mathrm{~s}$ and $60^{\circ} \mathrm{C}$ for $1 \mathrm{~min}$. with 2-min preincubation at $50^{\circ} \mathrm{C}$ required for optimal AmpErase UNG activity and 10 -min preincubation at $95^{\circ} \mathrm{C}$ required for activation of AmpliTaq Gold DNA polymerase. Each sample was analysed in triplicate.

The calibration curve was run in parallel with each analysis. The concentration of the of SRY and $\beta$-globin were expressed in genome-equivalents per millilitre of maternal plasma.

\section{Statistics}

Two-tailed t-test was performed using the SPSS software package for Windows. A P value of $<0.05$ was taken as statistically significant.

\section{Results}

Figure 1 and Figure 2 demonstrate standard curves for SRY and $\beta$-globin genes plotting the threshold cycle $\left(\mathrm{C}_{\mathrm{T}}\right)$ against known concentrations of serially diluted mixed DNA. Target quantity of unknowns was interpolated from given the $\mathrm{C}_{\mathrm{T}}$ of any unknown.

In our setting the sensitivity of the RQ-PCR system was $91,7 \%$ as SRY specific PCR amplicons were detected in 22 out of 24 studied samples and the specificity $100 \%$ since 


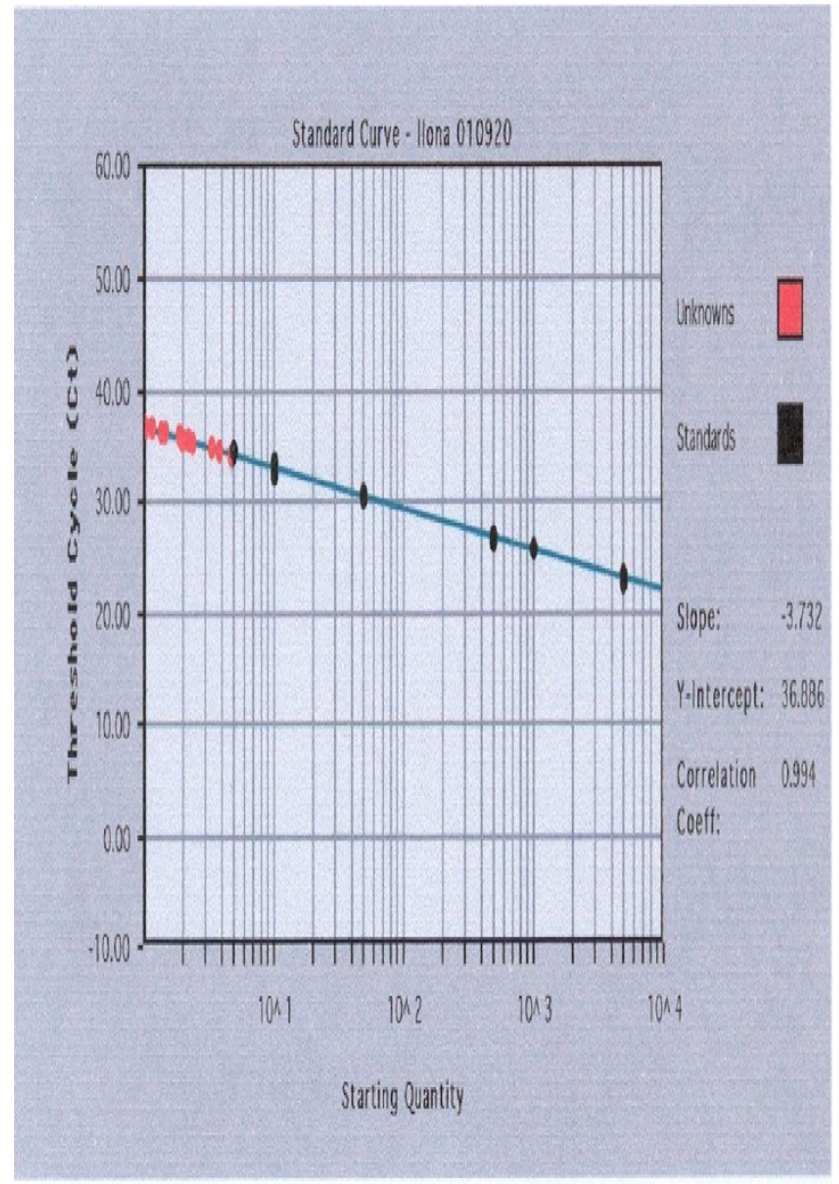

\section{Figure I}

Standard curve for SRY gene (in logarithmic scale) plotting the threshold cycle $\left(C_{T}\right)$ against known concentrations of serially diluted mixed DNA.

no $\mathrm{Y}$ chromosome positive signals were detected in 14 women currently pregnant with a female fetus.

The median fetal DNA levels in maternal plasma obtained from women carrying Down syndrome $(\mathrm{n}=11)$ and the controls carrying fetuses with normal karyotype $(\mathrm{n}=13)$ were 23,3 (range 0-58.5) genome-equivalents $/ \mathrm{ml}$ and 24,5 (range 0-47.5) genome-equivalents $/ \mathrm{ml}$. The difference between the two groups did not reach statistical significance $(\mathrm{P}=0.62)$, (Figure 3$)$.

The total median DNA levels in patients bearing fetuses affected with Down syndrome $(\mathrm{n}=16)$ and the controls carrying fetuses with normal karyotype $(\mathrm{n}=21)$ were 10165 (range 615 - 65000) genome-equivalents/ml and 7330 (range 1300 - 36750) genome-equivalents $/ \mathrm{ml}$ of maternal plasma, respectively $(\mathrm{P}=0.32)$, (Figure 4$)$.

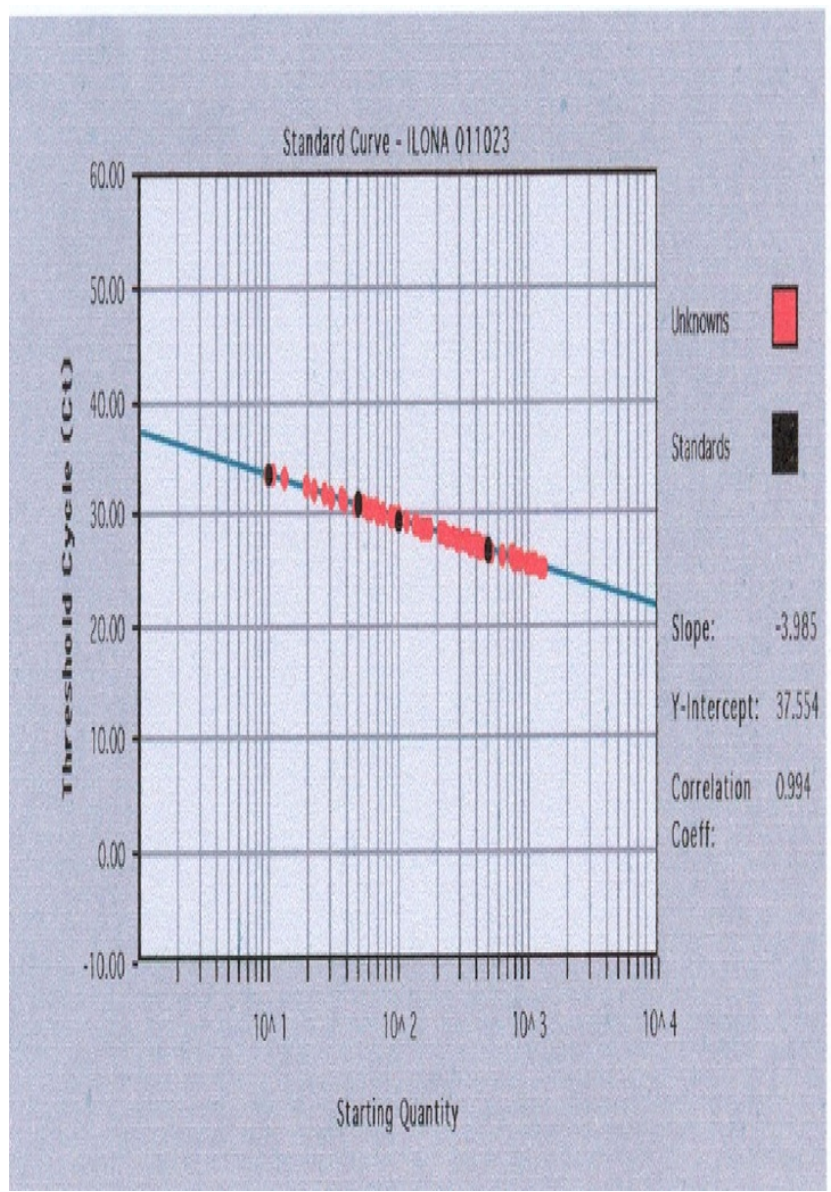

Figure 2

Standard curve for $\beta$-globin gene (in logarithmic scale) plotting the threshold cycle $\left(C_{T}\right)$ against known concentrations of serially diluted mixed DNA.

The fetal DNA proportion in maternal plasma was $0 \%-$ $6 \%$ (mean $0,8 \%$ ) in women carrying Down syndrome and $0 \%-2,6 \%$ (mean $0,7 \%$ ) in the controls carrying fetuses with normal karyotype, respectively $(\mathrm{P}=0.86)$.

\section{Discussion}

Recently, Lo et al. [9] reported findings of very high concentrations of circulating cell-free fetal DNA in maternal plasma in a proportion of pregnancies involving trisomy 21 fetuses. The median cell-free fetal DNA in women carrying trisomy 21 fetuses was found to be 2.96-fold and 1.97-fold higher than that of women carrying euploid fetuses in prospective studies done on samples collected from two centres. Consequently, Zhong et al. [10] confirm these results by showing elevated levels of fetal DNA in pregnancies with trisomy 21 fetuses (mean 185.6 genome-equivalents $/ \mathrm{ml}$ ) when compared to pregnancies with normal male fetuses (mean 83.1 genome-equivalents/ml). 


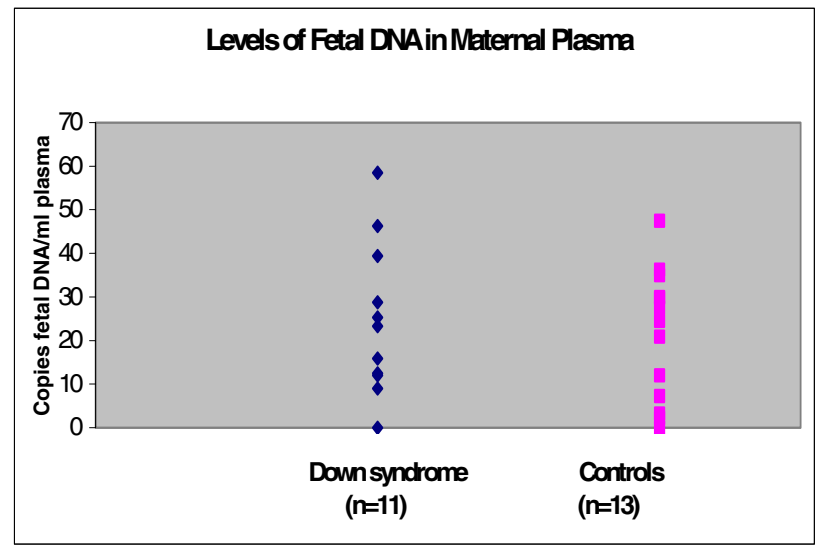

Figure 3

Levels of fetal DNA in maternal plasma.

Our results showed that fetal DNA levels in maternal plasma were not significantly elevated in pregnancies with Down syndrome fetuses when comparing to the controls carrying fetuses with normal karyotype. The median fetal DNA levels in maternal plasma obtained from women carrying Down syndrome $(\mathrm{n}=11)$ and the controls carrying fetuses with normal karyotype $(\mathrm{n}=13)$ were 23,3 (range 0-58.5) genome-equivalents/ml and 24,5 (range $0-47.5)$ genome-equivalents $/ \mathrm{ml}$, respectively $(\mathrm{P}=0.62)$. Plasma samples from women carrying euploid fetuses were recruited before amniocentesis for indications including maternal serum screening and advanced maternal age and compared with samples from women carrying Down syndrome fetuses sampling immediately as soon as possible after karyotype determination. Our data might confirm recently published results of Ohashi et al. independent study who observed no significant differencies in the levels of fetal DNA between pregnancies with fetuses of normal karyotype and those with Down and Edwards syndrome [12]. Several studies reported that plasma DNA concentration could be affected by different sample processing protocols $[13,14]$. The examination of only circulatory fetal DNA, any of initial processing steps concerning a single centrifugation of the blood sample or use of a discontinuous Percoll density gradient, as well as plasma fractions subsequently cleared further by highspeed centrifugation or filtration appear not to make significant difference in the concentration of fetal DNA $[13,14]$. However in case of maternal plasma, DNA concentrations may vary in various studies due to the level of clearing the plasma of any maternal cellular remnants. By using sample processing protocol concerning the double centrifugation of blood samples at $1200 \mathrm{~g}$ we found out comparable fetal DNA levels as those reported by Lo et al. who separated the plasma using double centrifugation at $3000 \mathrm{~g}$ [6]. Differences in total DNA levels and fetal DNA:

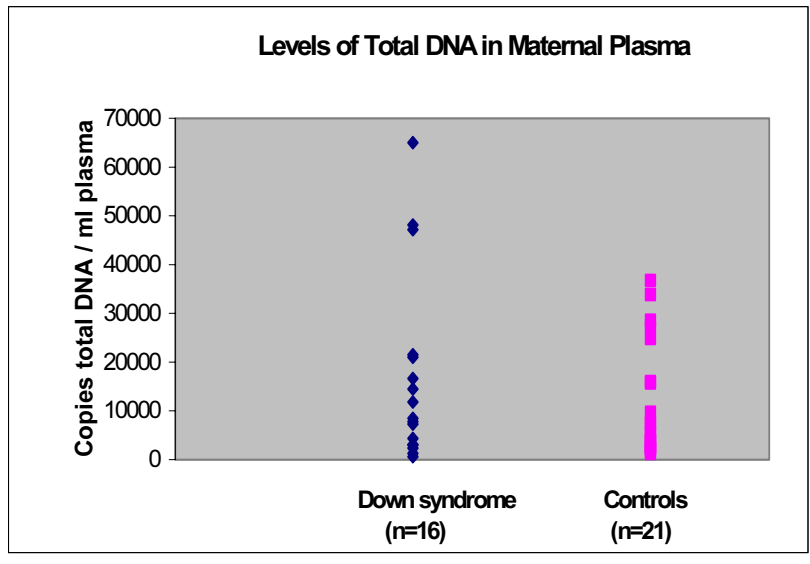

Figure 4

Levels of total DNA in maternal plasma.

maternal DNA ratio in maternal plasma between our results and those reported by Lo et al. [6] might be caused by the use of lower-speed and lower-time centrifugation protocol we used for plasma preparation in our study.

\section{Conclusions}

Our study revealed no difference in fetal DNA levels and fetal DNA: maternal DNA ratio between the patients carrying Down syndrome and the controls carrying fetuses with normal karyotype.

\section{Competing interests}

None declared.

\section{Authors' contributions}

IH designed the study and drafted the manuscript. BH, DH, SV carried out plasma sampling, DNA extraction and RQ-PCR studies. PC, KN, JK, DS, JD collected biological samples and reported clinical data. OC and JV participated in the design of the study.

\section{Acknowledgements}

This project was supported by the Internal Grant Agency, Ministry of Health, Czech Republic, project no: $4537-3$ and by $2^{\text {nd }}$ Medical faculty, Charles University in Prague, no: VZ III 300003.

\section{References}

I. Lo YMD, Corbetta N, Chamberlain PF, Sargent JL: Presence of fetal DNA in maternal plasma and serum. Lancet 1997, 350:485-487

2. Faas BH, Beuling EA, Christiaens GC, von dem Borne $A E$, van der Achoot CE: Detection of fetal RhD - specific sequences in maternal plasma. Lancet 1998, 352:। I 96

3. Lo YMD, Hjelm NM, Fidler C, Sargent IL, Murphy MF, Chamberlain PF, Poon PM, Redman CW, Wainscoat JS: Prenatal diagnosis of fetal RhD status by molecular analysis of maternal plasma. $\mathrm{N}$ engl J Med 1998, 339: 1734-1738

4. Hahn S, Zhong XY, Burk MR, Troeger C, Holzgreve W: Multiplex and realtime quantitative PCR on fetal DNA in maternal plasma: a comparison with fetal cells isolated from maternal blood: In Circulating DNA in Plasma, M Stroun, P Anker (eds). Ann N Y Acad Sci 2000, 906:148-152 
5. Zhong XY, Holzgreve W, Hahn S: Detection of fetal rhesus $D$ and sex using fetal DNA from maternal plasma by multiplex PCR. BJOG 2000, 107:766-769

6. Lo YMD, Tein MSC, Lau TK, Haines CJ, Leung TN, Poon PMK, Wainscoat JS, Johnson PJ, Chang AMZ, Hjelm NM: Quantitative analysis of fetal DNA in maternal plasma and serum. Implications for noninvasive prenatal diagnosis. Am J Hum Genet 1998, 62:768775

7. Lo YMD, Leung TN, Tein MS, Sargent IL, Zhang J, Lau TK, Haines CJ, Redman CW: Quantitative abnormalities of fetal DNA in maternal serum in preeclampsia. Clin Chem 1999, 45: 184-I88

8. Zhong XY, Laivuori H, Livingston JC, Ylikorbala O, Sibai BM, Holzgreve W, Hahn S: Elevation of both maternal and fetal extracellular circulating deoxyribonucleic acid concentrations in the plasma of pregnant women with preeclampsia. Am J Obstet Gynecol 200I, 184:414-419

9. Lo YMD, Lau TK, Zhang J, Leung TN, Chang AM, Hjelm NM, Elmas RS, Bianchi DW: Increased fetal DNA concentrations in the plasma of pregnant women carrying fetuses with trisomy $2 \mathrm{I}$. Clin Chem 1999, 45: 1747-I75।

10. Zhong XY, Burk MR, Troeger C, Jackson LR, Holzgreve W, Hahn S: Fetal DNA in maternal plasma is elevated in pregnancies with aneuploid fetuses. Prenat Diagn 2000, 20:795-798

II. Leung TN, Zhang J, Lau TK, Hjelm NM, Lo YMD: Maternal plasma fetal DNA as a marker for preterm labour. Lancet 1998, 352:1904-1905

12. Ohashi Y, Miharu N, Honda H, Samura O, Ohama K: Quantitation of fetal DNA in maternal serum in normal and aneuploid prenancies. Hum Genet 200I, 108: 123-127

13. Hahn S, Zhong XY, Holzgreve W: Quantification of Circulating DNA: In the Preparation Lies the Rub. Clin Chem 200 I, 47: I5771578

14. Chiu RWK, Poon LLM, Lau TK, Leung TN, Wong EMC, Lo YMD: Effects of blood-processing protocols on fetal and total DNA quantification in maternal plasma. Clin Chem 200I, 47:16071613

\section{Pre-publication history}

The pre-publication history for this paper can be accessed here:

http://www.biomedcentral.com/1471-2393/2/4/prepub

Publish with BioMed Central and every scientist can read your work free of charge

"BioMedcentral will be the most significant development for disseminating the results of biomedical research in our lifetime."

Paul Nurse, Director-General, Imperial Cancer Research Fund

Publish with BMC and your research papers will be:

- available free of charge to the entire biomedical community

- peer reviewed and published immediately upon acceptance

- cited in PubMed and archived on PubMed Central

- yours - you keep the copyright

Submit your manuscript here:

http://www.biomedcentral.com/manuscript/
BioMedcentral.com editorial@biomedcentral.com 